increase the potential for reviewers to adopt a reflective and analytic posture toward each book's contribution to scholarship. Its greatest effect probably was on the nature of the review essays, where essayists were encouraged to use the set of books selected for the essay as a platform to examine critically the theoretical and methodological issues regarding the specific research questions addressed in the books.

My impression is that expanded review length resulted in better reviews. The alternative-writing less about more-still seems somewhat misguided, if for no other reason than the poor use it makes of scholars' talents. I also believe that the contribution and quality of the Book Review as a whole is fundamentally based on the quality and contribution of the individual reviews. In the best of circumstances, the Book Review becomes not only a format for disseminating information about the existence of current scholarship but also a format for contemplating it in depth.

\section{Notes}

I first wish to thank Bing Powell for the opportunity to work as Book Review Editor and for his support during my editorship. The Book Review Office could not have functioned as smoothly as it did without the help of the graduate students who staffed it and assisted in every minor and major decision made. Nor would my experience as an editor have been nearly as pleasurable as it was. I thank Tim Fackler, Nathalie Frensley, Rodd Freitag, John Janssen, and Chris Marshall for their invaluable contributions. I especially thank Tim Fackler for assistance in preparing this report.

\title{
Report on the Status of Lesbians and Gays in the Political Science Profession
}

\section{Prepared by Committee on the Status of Lesbians and Gays in the Profession of the American Political Science Association ${ }^{1}$}

\section{Introduction}

Gay, lesbian, and bisexual visibility is such a recent phenomenon, and sexual diversity so little understood in the population at large, that the status of sexual minorities in the political science profession is difficult to decipher. ${ }^{2}$ While a number of other professional organizations established "status committees," and began research on these issues as early as the $1970 \mathrm{~s}$, the beginnings of a gay and lesbian caucus in political science attracted only modest numbers as recently as a decade ago, with most members wary of identifying their sexual orientation in a professional context. The mere idea of surveys such as those conducted by the APSA in September 1993 would have been unthinkable.

The APSA Council's establishment of the Committee on the Status of Lesbians and Gays in 1992 is one significant sign of change. ${ }^{3}$ So, too, is the growth of the Gay, Lesbian, Bisexual Political Science Caucus to a membership of 161 people, and its sponsorship (or cosponsorship) of 10 panels on gaylesbian related themes at the 1995 Annual Meeting.

Nevertheless, this history tells us little about the actual status of gays and lesbians in the professioneither as gays, lesbians, and bisexuals themselves view it, or as perceived by their heterosexual colleagues. The surveys of department chairs and of individual APSA members' opinions flag other signs of professional and institutional change in response to the challenge to create a more inclusive climate for sexual minorities. They also provide indications of how much remains to be done. These surveys reveal what political scientists would expect, that opinions vary greatly among both gays/lesbians/bisexuals and heterosexuals about the extent of inclusion and about appropriate responses. Perceptions among the latter are particularly varied, and any reading of their responses is inevitably confounded by the desire of most to avoid the subject altogether.

Any analysis of the 1993 surveys must begin, then, with an acknowledgment that they give us only fragmentary and prismatic glimpses of the status of gays and lesbians in the profession. Those individual Association members who took the questionnaire seriously enough to fill it in are obviously an unrepre- sentatively self-selective subset of Annual Meeting attenders or of the APSA more generally. ${ }^{4}$ That is true of the lesbian and gay members, and even more true of those who identify as heterosexual. The responses of all are reflective of their own particular perceptions of realities, no doubt filtered substantially by the perspectives they bring to all their observations.

The responses of department chairs must also be approached with caution. Many department chairs have had virtually no experience in thinking about sexual diversity issues. Those who did reply may well be those who had the strongest feelings (whether positive or negative). In addition, chairs could be expected to filter their perceptions on the basis of what they believe lies in the best interests of their departments.

All that said, how do we evaluate the status of gays, lesbians, and bisexuals in the profession of political science? In this report we explore a number of the measures addressed in the surveys. One indicator is the degree of visibility or "outness" of gays and lesbians in the profession, because achieving visibility is a crucial way to chal- 
lenge the codes of silence that prevent or slow institutional change. 5 It is also important, however, to explore what the consequences of these behaviors have been, and what sorts of supports (or barriers) colleagues have experienced to full participation in the discipline. Thus, among the factors we consider are (1) reported experiences and/or perceptions of discrimination (including evaluations of departmental and institutional "climate"); (2) the acceptability of research and writing on lesbian/ gay-related topics; and (3) the readiness of departments (and of particular people within them) to offer courses dealing with lesbian/ gay/bisexual themes. On each of these issues, we will be particularly interested in comparing the responses of self-identified gay/lesbian/bisexual respondents to those of their heterosexual colleagues, and to those of chairs.

\section{Surveying the Profession}

In the fall of 1992, the APSA Council formed the Committee on the Status of Lesbians and Gays in the Profession and, among other things, directed it to conduct a study of the status of lesbians and gays in political science. Accordingly, the Committee designed two surveys, one directed at chairs of political science departments across the United States, the second designed to reach the broader membership of the Association, heterosexual as well as gay/lesbian/

bisexual. The members' survey was included in the September 1993 issue of $P S$ and was widely available at the Annual Meeting of that year. The chairs' survey was distributed with the annual Departmental Services survey. Of the 765 chairs of departments granting political science degrees (B.A., M.A., or Ph.D.) who received the questionnaire, 280 , or $37 \%$, responded. 6 The membership survey elicited 459 responses, $25 \%$ of whom (116) identified as gay, lesbian, or bisexual. ${ }^{7}$

Interpretations of these surveys can be usefully informed by comparison with two others that have recently been conducted on the sta- tus of lesbians and gays in the professions of history and sociology. ${ }^{8}$ Those surveys point to significant change over the previous decade but, at the same time, report widespread experience of discrimination. There are, in fact, significant parallels between the political science surveys and those of these other academic professions, similarities to which we will refer as appropriate.

\section{Premises}

The Committee's charter, ${ }^{9}$ the 1993 surveys, and this report are premised, first, on the view that discrimination against people on the basis of their sexual orientation is inappropriate and that inquiry into the matter is professionally and intellectually indispensable. Second, they are informed by the view that a broad range of institutional practices (and interpersonal behaviors) may effectively marginalize gays, lesbians, and bisexuals, even if there is no intent to discriminate. One of the consequences is a degree of concealment of sexual orientation and personal life that would not be expected of heterosexuals. A third major premise is that the political science curriculum ought to incorporate attention to gay and lesbian issues. In this we imagine both an enriching of the traditional research and teaching agenda of political science and a recognition that full incorporation of new material may lead to the transformation of disciplinary categories. ${ }^{10}$

Responses to the 1993 surveys suggest that at least some in the profession questioned one or more of these premises, and therefore challenged the legitimacy of the questionnaires themselves. ${ }^{11}$

This is a ridiculous questionnaire-a waste of postage!

I resent having my dues money support this self-serving advocacy group!

Whole questionnaire is basically a bizarre exercise in irrelevance. (This is not to say there should be discrimination against homosexuals: there shouldn't be. The whole questionnaire is extremely childish.)
I am sorry our (my) membership money is being spent on such nonsensical matters. This is hardly worthy of the scholarly tradition APSA has always supported.

Why don't you survey about academic issues? Salary issues?

I seriously doubt the appropriateness of the APSA conducting a survey of this nature. It seems to be a basis for possible [charges of] harassment of a department or institution and has no relevance to the academic discipline.

There were also those in the profession who thanked the Association for undertaking this work:

I appreciate your efforts to look into this important issue.

Our campus is an extremely homophobic place for our gay/lesbian students. As a gay man and as political science department chair, I am particularly sensitive to these issues and concerns. Thank you for putting together this excellent survey.

\section{Coming Out and Being Out: Visibility and Invisibility}

The creation of institutional environments that welcome gay and lesbian visibility is central to the establishment of an inclusive profession. Invisibility has long been expected of, and in many settings enforced for, those with a sexual orientation other than heterosexual. As a result, many lesbians, gays, and bisexuals have been obliged to compartmentalize their existence and pretend that they have no personal lives. Because homosexual orientation has so commonly been construed to be only about sexual practice, and not about the broad range of relationships profoundly shaped by affectional preferences, it is not thought to be the proper subject of casual or intellectual discourse. The double standard becomes obvious when we note the frequency of public discussion of activities and relationships shaped by heterosexual attraction.

As Verta Taylor and Nicole Raeburn argued in introducing their report on surveys of lesbian and gay sociologists,

the movement to ban discrimination against lesbian, gay, and bisexual 
people depends heavily upon personal and individual strategies of "coming out," or publicly acknowledging one's gay, lesbian, or bisexual identity, to disrupt the codes of silence that block public recognition of gays and lesbians, mobilize group loyalty, and challenge institutionalized heterosexuality. ${ }^{12}$

They describe "coming out" as a form of "high-risk activism," one that carries with it substantial risk of discrimination and other forms of exclusion, even while it offers the possibility of "gain" in the form of community, support, and sense of well-being that go along with such membership. ${ }^{13}$

Some might well believe that the fact that people have come out is, in itself, an indicator that the world (or at least the academy, and political science, in particular) is now "safe" for gays and lesbians. Yet, substantial numbers of self-identified gays and lesbians who are "out" report having suffered from discrimination in one form or an- other. Both sociologists and historians reported that those who had come out, and had done research on lesbian/gay topics, believed that they had experienced discrimination-e.g., in hiring, promotion, etc.--even more among women than among men. Among all historians, for example, $70 \%$ reported having faced prejudice from colleagues, students, and/or administrators $(76 \%$ of women and $66 \%$ of men reported such experiences), and $43 \%$ reported experiencing some form of discrimination $(50 \%$ of women, $37 \%$ of men.) ${ }^{14}$ The sociologists' report noted that, while $27 \%$ of those surveyed in $1982 \mathrm{had}$ reported experiencing some discrimination in the profession on the basis of sexual identity, that figure had climbed to $43 \%$ in the 1992 survey. 15

Still, the climate has changed even over the past 10 to 15 years. The sociologists' survey was the second in just over a decade, and it reveals an important increase in the visibility of gays and lesbians (who were the principal target of both their questionnaires). In 1992, 54\% of the sociology respondents $(60 \%$ of men, and $32 \%$ of women) were "out" to their department chairs, up from $32 \%$ in 1981 .

One feature that emerges most strikingly from the APSA questionnaire responses is the small number of self-identified gays/lesbians/bisexuals in the profession, and the lower rates of visibility compared to both sociology and history. ${ }^{16}$ Only 116 political science respondents identified themselves as gay, lesbian, or bisexual, and we have to assume that the survey's focus would attract a high proportion of gay and lesbian members of the Association, particularly those who were "out" to any degree. ${ }^{17}$ There are assuredly members who so fully conceal their sexual orientation that they avoid responding even to a confidential question-

\section{FIGURE 1}

Number of Departments with LGB Faculty (Political Scientists-1993)

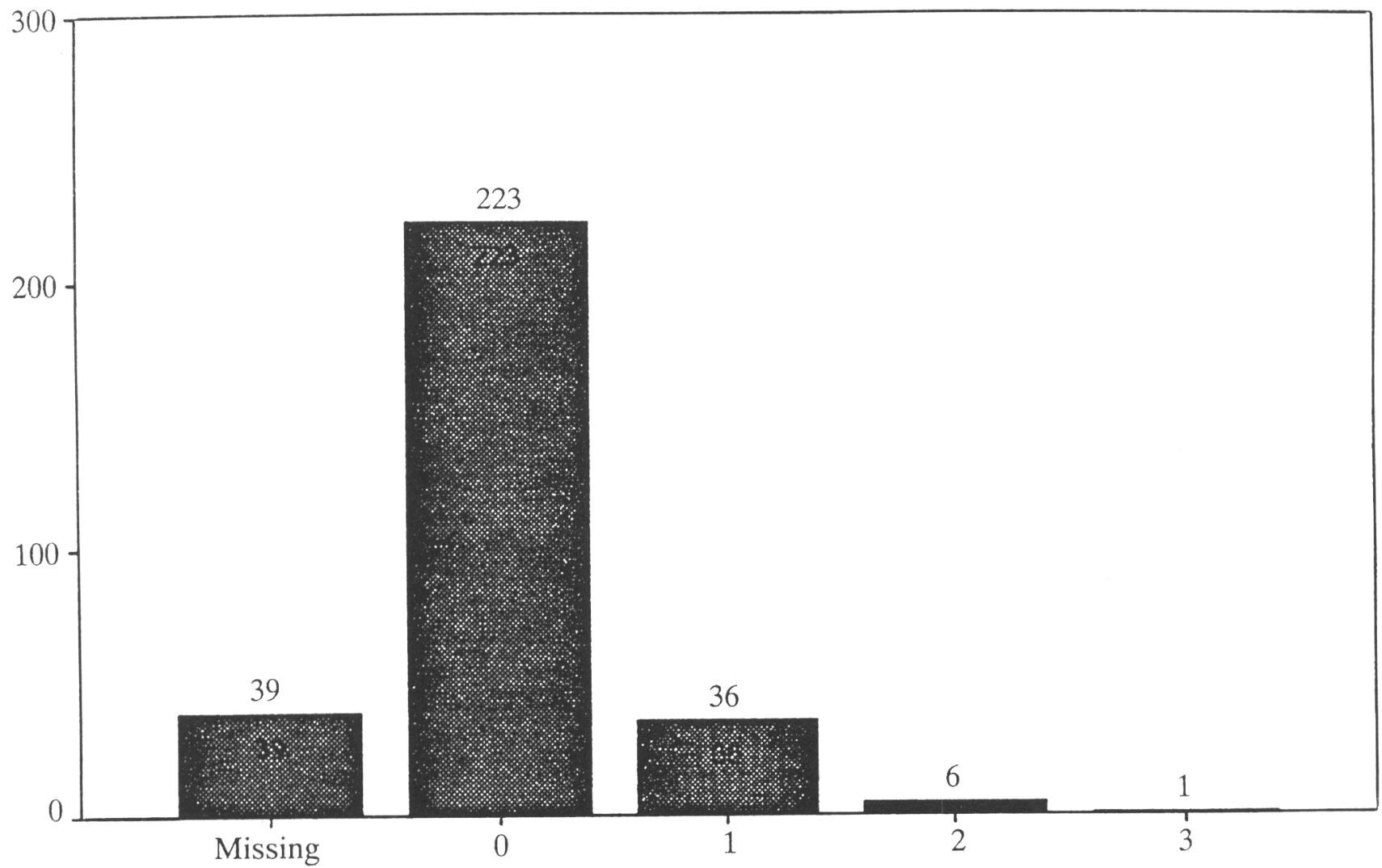

Known L/G Faculty-full-time

Source: APSA Survey of Department Chairs on the Status of Lesbians and Gays in the Profession 
naire. Just as revealing of the extent of invisibility is the survey of department chairs. In all of the departments for which information was available, there were only 49 full-time faculty members (of a total exceeding 2,300) known to their chairs to be lesbian or gay, and that number presumably includes some who are otherwise attempting to conceal their sexual orientation [see Figure 1].

Even of those 116 Association members who reported being lesbian, gay, or bisexual (most certainly lower than the total number of homosexuals), only 46 (about $40 \%$ ) said they were out to "everyone," and $25(22 \%)$ were not out to anyone at work (or were out only to other gays and lesbians). ${ }^{18} \mathrm{As}$ one respondent remarked in a summary comment,

I think that the most significant problem facing gays and lesbians is the ability, or rather inability, to come out in the respective departments. I think that there may be a few gay and lesbian faculty members at every school (university) I've attended, but none openly so. I think the scholarship on gay and lesbian politics is scarce, because I believe people are still afraid to do research in this area.

The pressures to conceal can easily affect groups already vulnerable on other counts. About $62 \%$ of the respondents identifying themselves as gay, lesbian or bisexual were male and $38 \%$ female. The men are substantially more likely to be fully out than are women: $46 \%$ of men, and only $32 \%$ of women, were out to almost everyone at work, while $20 \%$ of men and $32 \%$ of women were not out at all [see Table 1]. All but a handful of both lesbian and gay male respondents were white [see Table 2]. (Although the proportion of gay/lesbian/bisexual survey respondents who were out was higher among nonwhites than among whites, the numbers were exceedingly small and ratios therefore suspect.) All in all, the patterns reinforce perceptions of homosexuality as largely a white male phenomenon, and make it even harder for those who lie outside those categories to become visible.

\begin{tabular}{|c|c|c|c|}
\hline $\begin{array}{l}\text { Count } \\
\text { Col Pct }\end{array}$ & Male & Female & $\begin{array}{l}\text { Row } \\
\text { Total }\end{array}$ \\
\hline Out to all & $\begin{array}{l}28 \\
45.9\end{array}$ & $\begin{array}{l}12 \\
31.6\end{array}$ & $\begin{array}{l}40 \\
40.4\end{array}$ \\
\hline Out to some & $\begin{array}{l}21 \\
34.4\end{array}$ & $\begin{array}{l}14 \\
36.8\end{array}$ & $\begin{array}{l}35 \\
35.4\end{array}$ \\
\hline Not out & $\begin{array}{l}12 \\
19.7\end{array}$ & $\begin{array}{l}12 \\
31.6\end{array}$ & $\begin{array}{l}24 \\
24.2\end{array}$ \\
\hline $\begin{array}{r}\text { Column } \\
\text { Total }\end{array}$ & $\begin{array}{l}61 \\
61.6\end{array}$ & $\begin{array}{l}38 \\
38.4\end{array}$ & $\begin{array}{c}99 \\
100.0\end{array}$ \\
\hline
\end{tabular}

Patterns of visibility and concealment are also revealing when we explore differences by tenure status and age [see Tables 3, 4, 5]. Among tenured lesbian and gay faculty members, only $13 \%$ are not out at all on their campuses; but among untenured faculty members, the figure rises to $37 \%$. These figures are all the more striking when one realizes that in the population at large, younger gays and lesbians are more likely to be out than their older predecessors, not least because the environment in which they have matured is more supportive than that in which their older counterparts became adults [see Table 5]. ${ }^{19}$ Gender is also a factor here: among tenured faculty members, $59 \%$ of men and $43 \%$ of women are out to all; among untenured faculty members, $33 \%$ of men, but $48 \%$ of women are not out at all.

Evidence of the pressures for invisibility experienced by those aiming to enter the profession can be found in responses by depart-

\begin{tabular}{|c|c|c|c|}
\hline $\begin{array}{l}\text { Count } \\
\text { Col Pct }\end{array}$ & $\begin{array}{l}\text { NOT } \\
\text { LGB }\end{array}$ & LGB & $\begin{array}{l}\text { Row } \\
\text { Total }\end{array}$ \\
\hline White & $\begin{array}{c}291 \\
91.2\end{array}$ & $\begin{array}{c}105 \\
94.6\end{array}$ & $\begin{array}{l}396 \\
92.1\end{array}$ \\
\hline African American & $\begin{array}{c}13 \\
4.1\end{array}$ & $\begin{array}{l}3 \\
2.7\end{array}$ & $\begin{array}{l}16 \\
3.7\end{array}$ \\
\hline Latino & $\begin{array}{c}12 \\
3.8\end{array}$ & $\begin{array}{l}2 \\
1.8\end{array}$ & $\begin{array}{c}14 \\
3.3\end{array}$ \\
\hline Asian American & 1.3 & $\begin{array}{r}1 \\
.9\end{array}$ & ${ }^{2} .5$ \\
\hline Native American & 2.6 & & ${ }^{2} .5$ \\
\hline Column & 319 & 111 & $430^{\circ}$ \\
\hline
\end{tabular}

\begin{tabular}{|c|c|c|c|}
\hline $\begin{array}{l}\text { Count } \\
\text { Col Pct }\end{array}$ & $\begin{array}{l}\text { NOT } \\
\text { LGB }\end{array}$ & LGB & $\begin{array}{l}\text { Row } \\
\text { Total }\end{array}$ \\
\hline Graduate student & $\begin{array}{l}60 \\
18.4\end{array}$ & $\begin{array}{l}31 \\
27.4\end{array}$ & $\begin{array}{l}91 \\
20.7\end{array}$ \\
\hline $\begin{array}{l}\text { Nontenure trk } \\
\text { faculty }\end{array}$ & $\begin{array}{l}9 \\
2.8\end{array}$ & $\begin{array}{l}4 \\
3.5\end{array}$ & $\begin{array}{c}13 \\
3.0\end{array}$ \\
\hline Part-time faculty & $\begin{array}{c}14 \\
4.3\end{array}$ & $\begin{array}{l}8 \\
7.1\end{array}$ & $\begin{array}{c}22 \\
5.0\end{array}$ \\
\hline Tenured faculty & $\begin{array}{l}157 \\
48.2\end{array}$ & $\begin{array}{l}35 \\
31.0\end{array}$ & $\begin{array}{l}192 \\
43.7\end{array}$ \\
\hline Untenured faculty & $\begin{array}{l}86 \\
26.4\end{array}$ & $\begin{array}{l}35 \\
31.0\end{array}$ & $\begin{array}{l}121 \\
27.6\end{array}$ \\
\hline $\begin{array}{r}\text { Column } \\
\text { Total }\end{array}$ & $\begin{array}{l}326 \\
74.3\end{array}$ & $\begin{array}{c}113 \\
25.7\end{array}$ & $\begin{array}{l}439 \\
100.0\end{array}$ \\
\hline
\end{tabular}

mental chairs [Appendix]. When asked if they knew any openly gay/ lesbian/bisexual graduate students, only $10 \%$ responded affirmatively (67\% responding "don't know"). When asked about undergraduates, though, $38 \%$ responded "yes," indicating a significant drop as students moved into graduate schoola drop that we believe cannot be accounted for simply by smaller student populations. Closetedness is encouraged in many circles by views reflected in these responses by department chairs:

I do not consider questions regarding a colleague's sexuality appropriate.

I consider this inappropriate. It does not happen to be any of my business what the sexual behavior of my colleagues or students are.

None of the surveys' questions, of course, dealt with sexual behavior. Many of them, however, did deal with aspects of personal and pro-

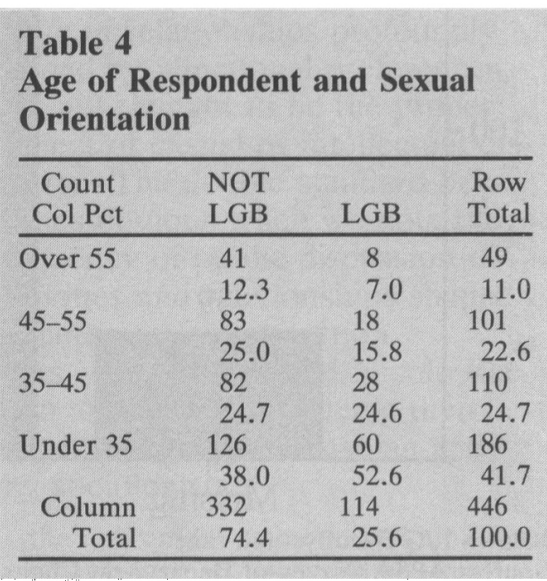




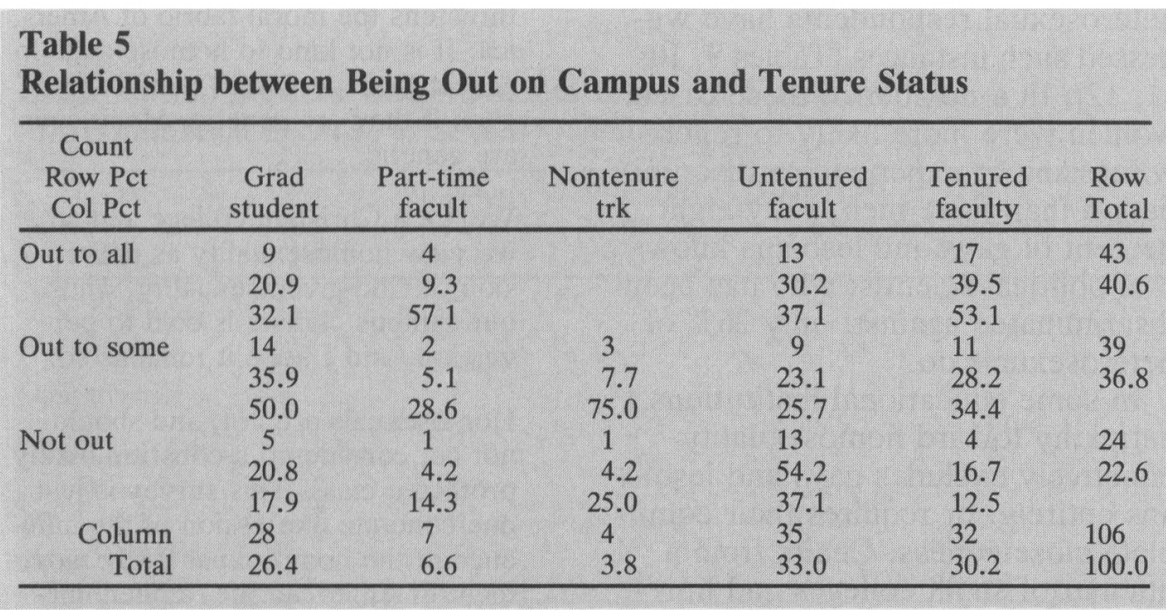

fessional life that are usually discussed openly by heterosexuals. Gays, lesbians, and bisexuals, then, are often pressured to maintain silence over aspects of life-such as parenting, vacation plans, or difficulties at home-about which heterosexuals are routinely public.

\section{Discrimination and Institutional Climate}

Preparedness to be visible is related, of course, to perceptions of the potential for professional harm and personal discomfort. Among gay/lesbian/bisexual political sci- ence respondents, $32 \%$ believe it probable or certain that they have been discriminated against because of their sexual orientation-and an additional $17 \%$ reported that they did not know whether they had [Figure 2]. As was the case with historians and sociologists, there were significant differences by gender. Forty-one percent of men, but only $26 \%$ of women, said they had, or probably had, experienced discrimination on the basis of sexual orientation, while $42 \%$ of men and $56 \%$ of women said that they probably or definitely had not [see Table 6]. As Taylor and Raeburn noted, these differences may well be accounted for either by the fact that it is difficult for women to differentiate discrimination on the basis of sexual orientation from that on the basis of gender, or by the fact that men are more likely to be fully out than are women [Table 1].

\section{FIGURE 2}

Experience of Job Discrimination by LGB Political Scientists

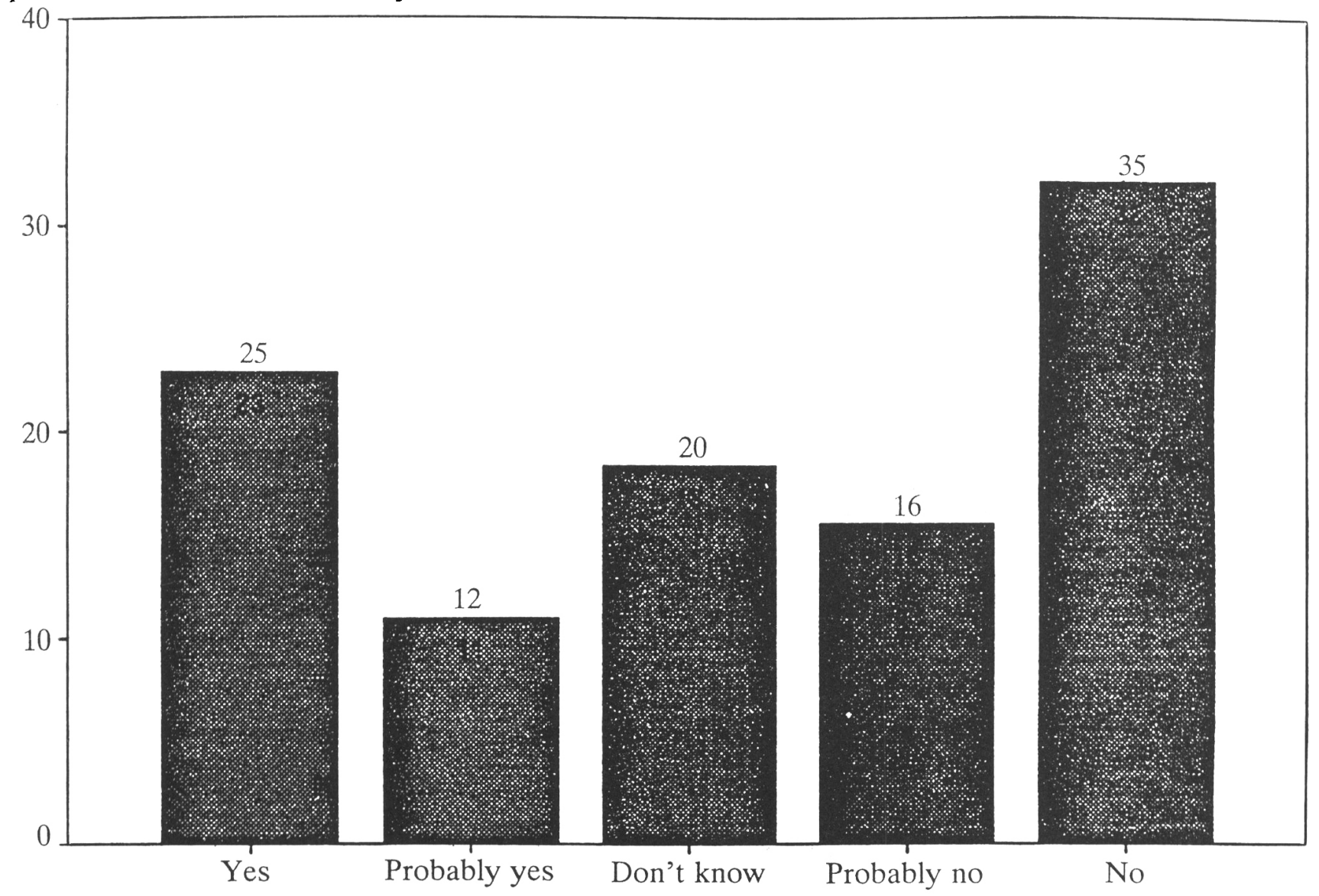

Did R ever face job discrimination for being LGB? 


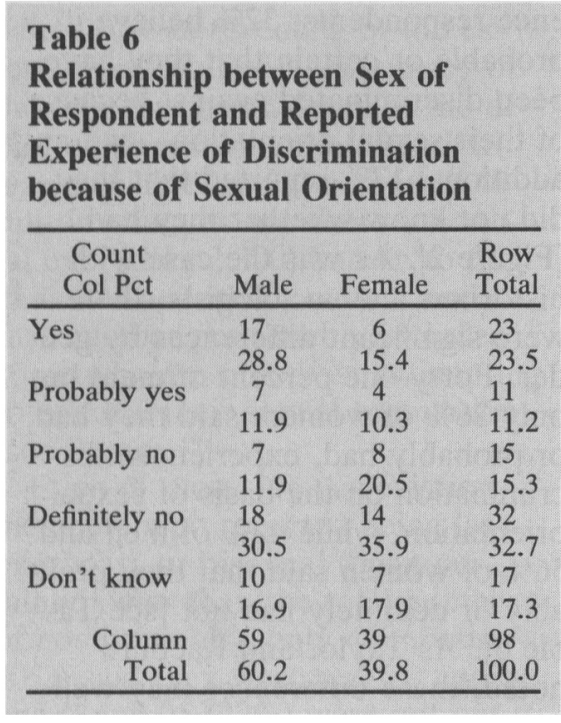

Particularly disturbing is the fact that the perception of discrimination is strongest in the most junior of cohorts, half of whom believe they have suffered discrimination, or that they probably have. When asked if their jobs would be at risk if their chairs knew they were gay/ lesbian, $18 \%$ of the youngest cohort believe that they would be, and only $44 \%$ were certain that they would not be; another $16 \%$ didn't know [Table 7]. ${ }^{20}$ Further, those who were out on their campus were more likely to report having experienced discrimination than those who were not: $48 \%$ of those who were out said they certainly or probably had experienced discrimination, as opposed to $30 \%$ of those who were not out; conversely, $29 \%$ of those who were out said they most likely had not experienced discrimination, whereas $57 \%$ of those who were not out said they had not [Table 8]. These are, of course, only perceptions, but they are powerfully suggestive of a climate that has improved far less than many would acknowledge.

Gay and nongay respondents have quite different views of the extent to which sexual minority status does harm. Over $40 \%$ of gay/ lesbian/bisexual respondents to the general survey claim to have experienced or witnessed instances where the perception that a person was homosexual was prejudicial in hiring, teaching evaluations, and collegial relations. Only $10-25 \%$ of heterosexual respondents have witnessed such instances [Tables 9, 10, $11,12]$. In a number of these cases, women were more likely to report witnessing or experiencing discrimination than were men. Fifty-eight percent of gays and lesbians know of a political scientist who has been discriminated against; only $26 \%$ of heterosexuals do.

In some educational institutions, antipathy toward homosexuality effectively excludes gays and lesbians entirely, or requires their complete closetedness. Chairs from a number of small colleges and universities suggested that the climate was not a welcoming one, though some respondents signaled regret at that state of affairs. In a couple of cases, chairs in Roman Catholic universities indicated that their colleagues and in some cases their students were prepared to talk about sexual orientation in an openminded way, but felt the constraints of administrations more closely tied to Church doctrine [see appendix]. That kind of ambivalence was not present in the responses from a few other chairs:

I believe that homosexuality is wrong. It hurts those who participate in it and the society that accepts it as equally valid to heterosexuality. It violates 10,000 years of Judeo-Christian moral standards and threatens the moral fabric of America. It is not kind to homosexuals to accept their perverse "preferences" even if they are genetic. Many evils are genetic....

We are a Christian college and so we view homosexuality as perversion of God-given sexuality. Thus, our campus climate is cold to perversion, and I hope it remains so.

Homosexuals are not, and should not be, considered a constitutionally protected class. This survey is just one concrete expression of the influence of the homosexual lobby movement in American life, a phenomenon not duplicated in any of the other 150 countries in the world with which I am familiar.

These sentiments were echoed in a few open-ended responses from Association members:

I embrace the traditional point of view that homosexuality is deviant, abnormal behavior. I would not discriminate against a person because of their sexual preference, however, I will not support nor endorse what is clearly a contradiction to the natural order of things.

I am frankly not interested in making their lives better, because I regard their behavior as repugnant. And the more overt it is, the less inclined I am to have anything to do with them. Assuming that they are discreet, I have fairly high tolerance

Table 7

Relationship between Believing Job at Risk and Date of Degree

\begin{tabular}{cccccc}
\hline $\begin{array}{c}\text { Count } \\
\text { Row Pct } \\
\text { Col Pct }\end{array}$ & $\begin{array}{c}1974 \text { and } \\
\text { early }\end{array}$ & $1975-84$ & $1985-89$ & $\begin{array}{c}1990 \text { and } \\
\text { Later }\end{array}$ & $\begin{array}{c}\text { Row } \\
\text { Total }\end{array}$ \\
\hline Definitely yes & 2 & 1 & 1 & 2 & 6 \\
& 33.3 & 16.7 & 16.7 & 33.3 & 5.6 \\
Probably yes & 12.5 & 5.3 & 5.9 & 3.6 & 10 \\
& 1 & & 1 & 8 & 9.3 \\
Probably no & 10.0 & & 10.0 & 80.0 & 16 \\
& 6.3 & 2 & 5.9 & 14.5 & 15.0 \\
Definitely no & 18.8 & 12.5 & 25.0 & 73.8 & 45 \\
& 18.8 & 10.5 & 23.5 & 12.7 & 42.1 \\
Don't know & 9 & 13 & 6 & 17 & 12 \\
& 20.0 & 28.9 & 13.3 & 37.8 & 11.2 \\
NA & 56.3 & 68.4 & 35.3 & 30.9 & 18 \\
& 1 & 1 & 1 & 9 & 16.8 \\
& 8.3 & 8.3 & 8.3 & 75.0 & 10.4 \\
& 6.3 & 5.3 & 5.9 & 12 & 100.0 \\
\hline Column & & 2 & 4 & 66.7 & \\
Total & 16 & 11.1 & 22.2 & 21.8 & \\
\hline
\end{tabular}


Table 8

Relationship between Being Out and Reported Experience of Discrimination because of Sexual Orientation

\begin{tabular}{|c|c|c|c|c|c|c|}
\hline $\begin{array}{l}\text { Count } \\
\text { Row Pct } \\
\text { Col Pct }\end{array}$ & $\begin{array}{c}\text { Yes } \\
1 \\
\end{array}$ & $\begin{array}{c}\text { Probably } \\
\text { Yes } \\
2 \\
\end{array}$ & $\begin{array}{c}\text { Probably } \\
\text { No } \\
3 \\
\end{array}$ & $\begin{array}{c}\text { Definitely } \\
\text { No } \\
4 \\
\end{array}$ & $\begin{array}{c}\text { Don't } \\
\text { Know } \\
5\end{array}$ & $\begin{array}{l}\text { Row } \\
\text { Total }\end{array}$ \\
\hline Out to all & $\begin{array}{l}14 \\
33.3 \\
56.0\end{array}$ & $\begin{array}{c}6 \\
14.3 \\
50.0\end{array}$ & $\begin{array}{c}5 \\
11.9 \\
31.3\end{array}$ & $\begin{array}{c}7 \\
16.7 \\
21.2\end{array}$ & $\begin{array}{l}10 \\
23.8 \\
52.6\end{array}$ & $\begin{array}{l}42 \\
40.0\end{array}$ \\
\hline Out to some & $\begin{array}{c}6 \\
15.0\end{array}$ & $\begin{array}{c}4 \\
10.0\end{array}$ & $\begin{array}{c}6 \\
15.0\end{array}$ & $\begin{array}{l}18 \\
45.0\end{array}$ & $\begin{array}{c}6 \\
15.0\end{array}$ & $\begin{array}{l}40 \\
38.1\end{array}$ \\
\hline Not out & $\begin{array}{c}5 \\
21.7 \\
20.0\end{array}$ & $\begin{array}{r}2 \\
8.7 \\
16.7\end{array}$ & $\begin{array}{c}5 \\
21.7 \\
31.3\end{array}$ & $\begin{array}{c}8 \\
34.8 \\
24.2\end{array}$ & $\begin{array}{c}3 \\
13.0 \\
15.8\end{array}$ & $\begin{array}{l}23 \\
21.9\end{array}$ \\
\hline $\begin{array}{r}\text { Column } \\
\text { Total }\end{array}$ & $\begin{array}{l}25 \\
23.8\end{array}$ & $\begin{array}{l}12 \\
11.4\end{array}$ & $\begin{array}{l}16 \\
15.2\end{array}$ & $\begin{array}{l}33 \\
31.4\end{array}$ & $\begin{array}{l}19 \\
18.1\end{array}$ & $\begin{array}{l}105 \\
100.0\end{array}$ \\
\hline
\end{tabular}

of male homosexuals. . . . But I simply detest lesbians, whose sexual proclivities I regard as a betrayal of real female friendship. So I can understand how men might well find their male counterparts unacceptable. . . . Would I discriminate against them? You bet-to exactly the degree their activities impinge on me. This lets out most undergraduate students and all activities that are purely intellectual matters. But hiring in a collegial department and mentoring are quite different matters.

Such beliefs are probably characteristic of faculty and students in a number of institutions, and certain aspects of these belief systems are common enough in the general population. Such views are regularly

\section{Table 9}

Relationship between Sexual Orientation and Preceptions of Discrimination in Hiring

Have you ever experienced or witnessed a situation in which you believe a person's perceived homosexuality helped, hurt, or was deemed irrelevant in hiring/ job search?

\begin{tabular}{rccc}
\hline $\begin{array}{c}\text { Count } \\
\text { Col Pct }\end{array}$ & $\begin{array}{c}\text { NOT } \\
\text { LGB }\end{array}$ & $\begin{array}{c}\text { LGB } \\
\text { Row } \\
\text { Total }\end{array}$ \\
\hline Hurt to be LGB & 42 & 44 & 86 \\
No impact to be & 14.0 & 42.7 & 21.4 \\
& 71 & 7 & 78 \\
Never saw it & 23.7 & 6.8 & 19.4 \\
& 172 & 43 & 215 \\
Helped to be LGB & 14 & 41.7 & 53.5 \\
& & 9 & 23 \\
Column & 299 & 103 & 402 \\
Total & 74.4 & 25.6 & 100.0 \\
\hline
\end{tabular}

given public voice in most university and college settings. Despite all the claims about the pervasiveness of "political correctness," public homophobia is still disturbingly widespread and unchallenged.

In an era when civil rights for gays and lesbians are increasingly a part of the general political agenda, one measure of climate on campus is the degree of comfort expressed -by both lesbian/gay/bisexual political scientists and their heterosexual colleagues-with a variety of gay/lesbian-related activities. Department chairs, for example, were surveyed about their degree of comfort (and that of departmental and institutional colleagues) with various "activities" by hypothetical gay or lesbian colleaguesactivities ranging from engagement in scholarly activity focusing on gay-related themes to publicly identifying oneself as gay or lesbian. When asked to provide their personal reactions to such things, chairs are generally inclined to be "accepting"' (as distinct from "tolerating, with some discomfort," or regarding an activity as "inappropriate"). They are significantly less accepting, however, in responding to the prospect of a colleague identifying her/himself as gay or lesbian in the classroom. Roughly the same pattern is evident in chairs' assessment of the reactions of their department colleagues, though with slightly greater discomfort about being out in the classroom [see appendix].

The most interesting discontinuity occurs with chairs' assessments of reactions in their institutions as a whole. Most chairs see their institutions as being accepting of research activities, but being much less tolerant of activities that entail greater publicity on campus or in the surrounding community. When asked about presenting a paper on lesbian/gay topics at an APSA meeting, overwhelming majorities reported themselves, their departments, and their institutions as accepting (86\%, $81 \%$ and $73 \%)$. Not surprisingly, perhaps, those at religiously identified institutions differed from this norm: chairs at $64 \%$ of such institutions (compared with $89 \%$ at public institutions, and $81 \%$ at nondenominational private ones) said their institutions would be accepting; but a full $18 \%$ said their institutions would consider such activity inappropriate.

On at least some campuses, then, "being" gay or lesbian is fine, as is doing research or publishing in the area of sexual orientation. But being public about one's sexual orientation is much more likely to create discomfort if not outright hostility. Overall, chairs of only $31 \%$ of institutions said their institutions would be likely to find identifying oneself as gay or lesbian in the classroom to be "acceptable" behavior. Regional differences were striking here: $49 \%$ of chairs whose institu-

Table 10

Relationship between Sexuality and Perceptions of Discrimination in Reappointment or Tenure

Have you ever experienced or witnessed a situation in which you believe a person's perceived homosexuality helped, hurt, or was deemed irrelevant in reappointment or tenure?

\begin{tabular}{rclc}
\hline $\begin{array}{c}\text { Count } \\
\text { Col Pct }\end{array}$ & $\begin{array}{c}\text { NOT } \\
\text { LGB }\end{array}$ & $\begin{array}{l}\text { LGB } \\
\text { Row } \\
\text { Total }\end{array}$ \\
\hline Hurt to be LGB & 34 & 30 & 64 \\
& 11.6 & 30.0 & 16.3 \\
No impact to be & 75 & 13 & 88 \\
& 25.6 & 13.0 & 22.4 \\
Never saw it & 177 & 51 & 228 \\
& 60.4 & 51.0 & 58.0 \\
Helped to be LGB & 7 & 6 & 13 \\
& 2.4 & 6.0 & 3.3 \\
Column & 293 & 100 & 393 \\
Total & 74.6 & 25.4 & 100.0 \\
\hline
\end{tabular}


Table 11

Relationship between Sexuality and Perceptions of Discrimination in Collegial Relations

\begin{tabular}{rccc}
\hline $\begin{array}{c}\text { Count } \\
\text { Col Pct }\end{array}$ & $\begin{array}{c}\text { NOT } \\
\text { LGB }\end{array}$ & LGB & $\begin{array}{c}\text { Row } \\
\text { Total }\end{array}$ \\
\hline Hurt to be LGB & 74 & 53 & 127 \\
& 24.9 & 50.5 & 31.6 \\
No impact to be & 64 & 15 & 79 \\
& 21.5 & 14.3 & 19.7 \\
Never saw it & 151 & 27 & 178 \\
& 50.8 & 25.7 & 44.3 \\
Helped to be LGB & 8 & 10 & 18 \\
& 2.7 & 9.5 & 4.5 \\
Column & 297 & 105 & 402 \\
Total & 73.9 & 26.1 & 100.0 \\
\hline
\end{tabular}

tions were located in the North or West said such behavior would be acceptable in their institutions, compared to $30 \%$ of those in the Midwest and $24 \%$ in the South. Conversely, $23 \%, 10 \%, 31 \%$, and $35 \%$, respectively, said their institutions would deem this behavior "inappropriate." We find similar differences among the types of institutions surveyed: $44 \%$ of those in public institutions, $37 \%$ of those in nondenominational private institutions, but only $12 \%$ of those in religiously identified institutions said such behavior would be acceptable on their campuses; while a full $58 \%$ of chairs at such institutions said that identifying oneself in the classroom would be considered "inap-

Table 12

Relationship between Sexuality and Perceptions of Discrimination with Respect to Publications

Have you ever experienced or witnessed a situation in which you believe a person's perceived homosexuality helped, hurt, or was deemed irrelevant in publication?

\begin{tabular}{cccc}
\hline $\begin{array}{c}\text { Count } \\
\text { Col Pct }\end{array}$ & $\begin{array}{c}\text { NOT } \\
\text { LGB }\end{array}$ & $\begin{array}{c}\text { LGB } \\
\text { Low } \\
\text { Total }\end{array}$ \\
\hline Hurt to be LGB & 4 & 20 & 24 \\
No impact & 1.4 & 20.8 & 6.3 \\
Never saw it & 69 & 17 & 86 \\
Helped to be LGB & 24.0 & 17.7 & 22.4 \\
& 72.2 & 57.3 & 68.5 \\
Column & 288.4 & 4 & 11 \\
Total & 75.0 & 25.0 & 2.9 \\
\hline
\end{tabular}

propriate" [appendix]. As one chair characterized his institution, "Quiet' openness is OK. Advocacy has not occurred and so probably is not OK. School works fairly hard on sexual harassment, but not on sexual orientation."

Open-ended responses by a few Association members and chairs suggested that student prejudice was an additional impediment to full equality. Some argued that in their institutions students were more homophobic than either faculty or administrators, one elaborating in terms suggesting that junior faculty were most vulnerable:

Where political scientists suffer most is in the classroom. Most students react extremely negatively toward a professor being gay or lesbian or bisexual, and worse if you are transgendered or transvestite (which I am not).

Other "liberal" students pay lip service to accepting the professor's sexuality, but toleration is a more apt phrase than acceptance and when push comes to shove these students "cave in" rather easily to their peers. Since student evaluations play a major role in determining a prospective hire's abilities, revealing or becoming known as gay or lesbian or bisexual or "other" to students results in much lower evaluations. This is especially hard on graduate students seeking first jobs.

Taken together, these responses suggest that the institutional/departmental climate on some campuses is considerably less welcoming than many would like to believe.

Networks. One of the consequences faced by many gay/lesbian/ bisexual political scientists is exclusion from social and professional networks within and beyond their institutions. At most departmental social events (and even more commonly at the institutional level), gay and lesbian relationships are made invisible. (Among sexual minority political scientists, only $30 \%$ reported that their partners were included in most departmental social gatherings, and only $12 \%$ reported inclusion at the institutional level. $)^{21}$ As individuals, many gays and lesbians experience similar exclusion from the kind of networks that often blend socializing with professional concerns.

One of the challenges facing gay and lesbian people is simply being in the loop, and getting the advantage of all the information which flies around programs about surviving, getting by, who is doing what, etc., which is never written down but can be important to performing successfully.

Institutional Policy. Responses by department chairs to other questions provide evidence of some institutional acknowledgment of rights for gays, lesbians, and bisexuals. Most chairs indicated that they would take seriously a complaint about an anti-gay/lesbian remark by a colleague. Close to twothirds of their institutions now include sexual orientation in their nondiscrimination policies and have gay/lesbian student organizations on their campuses, the overwhelming majority of these receiving institutional support.

On the other hand, while most nondiscrimination policies include sexual orientation, only a small minority of benefit programs include nonmarried domestic partners, or same-sex partners. As one gay/ lesbian/bisexual respondent commented,

There is a very narrow view of these issues. The biggest problem is one of open attitudes and covert biasinstitutions which scream "we're accepting" and then do not allow insurance to cover [same-sex] significant others.

The general failure to recognize same-sex relationships goes beyond "benefits" policies. Lesbians and gays in long-term relationships have to consider employment prospects for their partners when considering a new job. Some institutions take up the issue of employment for a partner, but almost entirely in heterosexual terms.

A substantial proportion of institutions have created faculty development funds targeted for "diversity" (47\% of chairs reported the existence of such funds at their institution); but only $13 \%$ of chairs reported that gay/lesbian issues were included under that rubric [appendix]. Some institutions are nervous about overt policy inclusion of gays and lesbians, as this department 
chair observed, reinforcing other sources of reservation and resistance:

Acceptance of gays or lesbians, whether students or faculty, would be viewed by faculty in terms of political correctness, by male students as a threat to their masculinity and by administrators (and trustees) as a potential threat to image and fundraising. . . . There is no policy pertaining to the matter, but activism would be viewed in the context of impact on institutional image.

\section{Research on Gay/Lesbian Topics}

Another indicator of the climate for sexual minorities in the profession is the amount of research on gay/lesbian topics being undertaken by political scientists, and attitudes toward its appropriateness. Of course, not every gay, lesbian, or bisexual political scientist wishes to engage in research on these topics. Nevertheless, when we compare views of the appropriateness of research on these topics by sexual orientation [Table 13], and explore the question of whether political scientists have ever been encouraged or discouraged from engaging in research on such topics, we find some reason for concern. As we have indicated, chairs' responses evince relative comfort with colleagues engaging in research and publishing on gay/lesbian issues. When asked how many faculty members in their departments had published on gay/lesbian themes, $12 \%$ reported at least one.

On the other hand, only $39 \%$ of

\begin{tabular}{|c|c|c|c|}
\hline $\begin{array}{l}\text { Count } \\
\text { Col Pct }\end{array}$ & $\begin{array}{l}\text { NOT } \\
\text { LGB }\end{array}$ & LGB & $\begin{array}{l}\text { Row } \\
\text { Total }\end{array}$ \\
\hline Very appropriate & $\begin{array}{c}120 \\
38.7\end{array}$ & $\begin{array}{l}77 \\
70.0\end{array}$ & $\begin{array}{c}197 \\
46.9\end{array}$ \\
\hline Appropriate & $\begin{array}{c}134 \\
43.2\end{array}$ & $\begin{array}{l}21 \\
19.1\end{array}$ & $\begin{array}{c}155 \\
36.9\end{array}$ \\
\hline Not appropriate & $\begin{array}{l}56 \\
18.1\end{array}$ & $\begin{array}{l}12 \\
10.9\end{array}$ & $\begin{array}{l}68 \\
16.2\end{array}$ \\
\hline Column & 310 & 110 & 420 \\
\hline Total & 73.8 & 26.2 & 100.0 \\
\hline
\end{tabular}

heterosexual respondents said research on gay/lesbian topics was very appropriate in their subfield. Among lesbian/gay/bisexual respondents $70 \%$ believed such research was very appropriate, but $22 \%$ reported that they had been discouraged from engaging in such research, and 39\% reported that they had avoided pursuing research on these topics for fear that it would not be taken as "serious political science" [see Tables 14, 15]. (Among heterosexual respondents, $3 \%$ reported that they had been discouraged from engaging in such research, and 5\% that they had avoided it for fear of it not being taken as serious research.)

On a number of member surveys, there were comments challenging the appropriateness of studying gay and lesbian issues. Some were supportive of the principle of examining sexual identity issues in political science, but questioned the legitimacy of a distinct field of gay/ lesbian studies. (Similar debates can be found regarding women's studies, African-American studies, and Latino/Chicano studies.) Others challenged more fundamentally the scholarly relevance of any inquiry by political scientists into sexual minority issues:

This is not a scholarly field. It is a farce, unworthy of study. It detracts from legitimate inquiry.

The most significant problem facing homosexuals is also the number one problem facing all of us in the profession-pseudo-scholarship, i.e., gay and lesbian studies.

As one respondent to the member survey observed:

I think that the most significant problem for gay and lesbian political scientists is a problem which affects everyone in the field. The social sciences which emerged from a liberal ideology embedded in enlightenment beliefs also have been profoundly affected by the Progressive perspective on the neutrality of science and the power of "professional" neutral administration. Consequently, professors convince themselves that the abstract generalizations central to the prevailing paradigms cooked up in the ivory tower have a universal application. At the same time, our own experiences and lives (gays, lesbians, women, people of color)
Table 14

Have You Ever Been Encouraged or Discouraged from Conducting Research on Gay or Lesbian Topics?

\begin{tabular}{|c|c|c|c|}
\hline $\begin{array}{l}\text { Count } \\
\text { Col Pct }\end{array}$ & $\begin{array}{l}\text { NOT } \\
\text { LGB }\end{array}$ & LGB & $\begin{array}{l}\text { Row } \\
\text { Total } \\
\end{array}$ \\
\hline Strongly encouraged & $\begin{array}{l}3 \\
1.0\end{array}$ & $\begin{array}{l}11 \\
10.5\end{array}$ & $\begin{array}{c}14 \\
3.4\end{array}$ \\
\hline Encouraged & $\begin{array}{c}14 \\
4.5\end{array}$ & $\begin{array}{l}14 \\
13.3\end{array}$ & $\begin{array}{l}28 \\
6.8\end{array}$ \\
\hline Neither & $\begin{array}{l}281 \\
91.2\end{array}$ & $\begin{array}{l}57 \\
54.3\end{array}$ & $\begin{array}{l}338 \\
81.8\end{array}$ \\
\hline Discouraged & $\begin{array}{l}7 \\
2.3\end{array}$ & $\begin{array}{l}19 \\
18.1\end{array}$ & $\begin{array}{l}26 \\
6.3\end{array}$ \\
\hline Strongly discouraged & $\begin{array}{l}3 \\
1.0\end{array}$ & $\begin{array}{l}4 \\
3.8\end{array}$ & $\begin{array}{l}7 \\
1.7\end{array}$ \\
\hline $\begin{array}{r}\text { Column } \\
\text { Total }\end{array}$ & $\begin{array}{l}308 \\
74.6\end{array}$ & $\begin{array}{l}105 \\
25.4\end{array}$ & $\begin{array}{l}413 \\
100.0\end{array}$ \\
\hline
\end{tabular}

are strangely barely even included in the margins of the context for investigation. We are trained that an acceptance of this alienation of our experience from our intellectual pursuits is a sign of objectivity, rather than an absurdity which disturbs our ability to even pose questions relevant to our own experience of the world.

One indicator of an increase in gay/lesbian visibility is the report from just over $10 \%$ of department chairs that job openings had attracted openly gay/lesbian applicants, and from about $16 \%$ that they had received applications indicating gay/lesbian research interests. But no chairs indicated that being gay or lesbian is thought to be an asset in recruiting - that the hiring of a political scientist (gay/ lesbian or heterosexual) with an interest in sexual minority issues would constitute a net gain for the

\begin{tabular}{|c|c|c|c|}
\hline \multicolumn{4}{|c|}{$\begin{array}{l}\text { Table } 15 \\
\text { Have You Ever Avoided Pursuing } \\
\text { Research on These Topics out of } \\
\text { Concern That It Would Not Be } \\
\text { Considered "Serious Political } \\
\text { Science"? }\end{array}$} \\
\hline $\begin{array}{l}\text { Count } \\
\text { Col Pct }\end{array}$ & $\begin{array}{l}\text { NOT } \\
\text { LGB }\end{array}$ & LGB & $\begin{array}{l}\text { Row } \\
\text { Total }\end{array}$ \\
\hline No & $\begin{array}{c}292 \\
94.8\end{array}$ & $\begin{array}{l}69 \\
61.1\end{array}$ & $\begin{array}{c}361 \\
85.7\end{array}$ \\
\hline Yes & $\begin{array}{c}16 \\
5.2\end{array}$ & $\begin{array}{l}44 \\
38.9\end{array}$ & $\begin{array}{l}60 \\
14.3\end{array}$ \\
\hline $\begin{array}{r}\text { Column } \\
\text { Total }\end{array}$ & $\begin{array}{c}308 \\
73.2\end{array}$ & $\begin{array}{c}113 \\
26.8\end{array}$ & $\begin{array}{l}421 \\
100.0\end{array}$ \\
\hline
\end{tabular}


department and the profession. Fully $43 \%$ of sexual minority respondents (and 14\% of heterosexuals) reported having experienced or witnessed hiring processes in which a person's perceived homosexuality hurt that person's chances of success [Table 9].

\section{Gays/Lesbians and the University Curriculum}

Another indication of the status of sexual minorities and the professional climate they face is the readiness of departments, and of particular people in them, to offer courses dealing with lesbian/gay/ bisexual themes. Here we find considerable marginalization. According to the chairs' reports, only a tiny proportion of departments offer as much as a single course with gay/lesbian topics as a primary theme ( $1 \%$ for graduate courses, $3 \%$ for undergraduate) [see appendix], and among those without such offerings, there has been almost no expression of interest in establishing them-either from faculty or from students. About $6 \%$ of departments claim at least one course at the graduate level in which such topics are one of a number of themes or topics, and just over one-third make the same claim about undergraduate courses, though with no indication of how significant a topic, and in how many courses. ${ }^{22}$ Eighty-seven percent of chairs reported that their departments rarely or never sponsored lectures on gay politics.

It is encouraging that over $60 \%$ of the heterosexual respondents to the general survey said they included gay/lesbian-related topics in their teaching in some way [Tables $16,17,18,19$, Fig 3, 4]. Some of the department heads, in fact, were able to report progress in surprising places. One of them noted the increased interest in gay-related issues among his students, a number of whom were military personnel:

For the past five years or so I have covered, in the American Government courses, sexual orientation as part of the civil rights movement of the 1960 s, etc. ... With the candidacy of Bill Clinton and "homosexu-

\begin{tabular}{|c|c|c|c|}
\hline \multicolumn{4}{|c|}{$\begin{array}{l}\text { Table } 16 \\
\text { How Appropriate Are } \\
\text { Undergraduate Courses on } \\
\text { Lesbian or Gay Politics in } \\
\text { Political Science? }\end{array}$} \\
\hline $\begin{array}{c}\text { Count } \\
\text { Col Pct }\end{array}$ & $\begin{array}{l}\text { NOT } \\
\text { LGB }\end{array}$ & LGB & $\begin{array}{l}\text { Row } \\
\text { Total }\end{array}$ \\
\hline Very appropriate & 67 & $\begin{array}{l}65 \\
565\end{array}$ & 132 \\
\hline Appropriate & $\begin{array}{c}137 \\
42.8\end{array}$ & $\begin{array}{l}32 \\
27.8\end{array}$ & $\begin{array}{c}169 \\
38.9\end{array}$ \\
\hline Not appropriate & $\begin{array}{c}116 \\
36.3\end{array}$ & $\begin{array}{l}18 \\
15.7\end{array}$ & $\begin{array}{c}134 \\
30.8\end{array}$ \\
\hline & & & 435 \\
\hline
\end{tabular}

als in the military," homosexuality has increased in importance, interest, and intensity. In the U.S. Foreign Policy course last year, we had an excellent unit on this topic.

Another chair, from a department sufficiently small that covering even the basics is a struggle, indicated a degree of institutional preparedness to encourage student exploration of such topics.

We barely cover the major areas of international, comparative, theory, administration, and American. We encourage topical selections within those standard courses which are inclusive of diverse issues and concerns. We facilitate internships of many kinds, including some at organizations such as Gay Men's Health Crisis.

These were not typical responses. Among heterosexual respondents to the member survey, $40 \%$ indicated that they did not include gay/lesbian topics even occasionally in their teaching (though women were twice as likely as men to include them. In that light, it is dishearten-

\section{Table 17}

Do You Include Lesbian/Gay Topics in Your Teaching?

\begin{tabular}{rclc}
\hline $\begin{array}{c}\text { Count } \\
\text { Col Pct }\end{array}$ & $\begin{array}{c}\text { NOT } \\
\text { LGB }\end{array}$ & LGB & $\begin{array}{c}\text { Row } \\
\text { Total }\end{array}$ \\
\hline No & 116 & 15 & 131 \\
On occasion & 146.6 & 15.3 & 33.5 \\
& 49.8 & 44 & 190 \\
Regularly & 31 & 39.9 & 48.6 \\
& 10.6 & 39.8 & 70 \\
Column & 293 & 98 & 391 \\
Total & 74.9 & 25.1 & 100.0 \\
\hline
\end{tabular}

\section{Table 18}

How Appropriate Is It to Integrate Topics on Lesbian or Gay Politics into Undergraduate Course?

\begin{tabular}{|c|c|c|c|}
\hline $\begin{array}{l}\text { Count } \\
\text { Col Pct }\end{array}$ & $\begin{array}{l}\text { NOT } \\
\text { LGB }\end{array}$ & LGB & $\begin{array}{l}\text { Row } \\
\text { Total }\end{array}$ \\
\hline Very appropriate & $\begin{array}{c}129 \\
40.1\end{array}$ & $\begin{array}{l}85 \\
73.9\end{array}$ & $\begin{array}{r}214 \\
49.0\end{array}$ \\
\hline Appropriate & $\begin{array}{r}142 \\
44.1\end{array}$ & $\begin{array}{l}22 \\
19.1\end{array}$ & $\begin{array}{r}164 \\
37.5\end{array}$ \\
\hline Not appropriate & $\begin{array}{l}51 \\
15.8\end{array}$ & $\begin{array}{l}8 \\
7.0\end{array}$ & $\begin{array}{l}59 \\
13.5\end{array}$ \\
\hline Column & 322 & 115 & $\begin{array}{l}437 \\
1000\end{array}$ \\
\hline
\end{tabular}

ing to note the number of political scientists who believe that it is important to integrate sexual diversity issues into the regular curriculum rather than create pedagogical ghettos, but who fail to act on their stated beliefs. Among all political scientists, for example, $52 \%$ of those who say it is very appropriate to integrate gay and lesbian topics into undergraduate courses actually do include them in their teachings, while only $9 \%$ of those who say it is "appropriate" to do so actually do include them.

Not surprisingly, perhaps, there seems to be a strong relationship between being gay, lesbian, or bisexual and teaching materials on the politics of sexuality. Among heterosexual political scientists, $40 \%$ say it is "very appropriate" to integrate topics on lesbian or gay politics into undergraduate courses, and another $44 \%$ say it is "appropriate"; while comparable figures for lesbian/gay political scientists are $74 \%$ and $19 \%$ [see Table 18]. But when we compare how many of these actually include such top-

\section{Table 19}

Do Any Courses You Teach

Have $10 \%$ or More Lesbian or Gay-Related Content?

\begin{tabular}{llll}
\hline $\begin{array}{c}\text { Count } \\
\text { Col Pct }\end{array}$ & NOT & RGB & $\begin{array}{c}\text { Row } \\
\text { Total }\end{array}$ \\
\hline No & 177 & 46 & 223 \\
& 83.1 & 55.4 & 75.3 \\
Yes & 36 & 37 & 73 \\
& 16.9 & 44.6 & 24.7 \\
Column & 213 & 83 & 296 \\
Total & 72.0 & 28.0 & 100.0 \\
\hline
\end{tabular}


ics in their teaching, the differences are striking: $42 \%$ of heterosexual political scientists who say it is "very appropriate" to integrate materials on lesbian/gay politics into undergraduate courses actually do so. Among gay/lesbian/bisexual political scientists, however, $66 \%$ of those who believe such integration to be "very appropriate" actually $d o$ include such materials. In any case, the relatively small numbers of courses available-particularly given the substantial percentage of those who believe material related to sexuality appropriate for undergraduate and/or graduate teaching (among heterosexual political scientists, $70 \%$ believed graduate seminars on lesbian or gay politics were appropriate, and $64 \%$ believed undergraduate courses on such topics were appropriate; the comparable figures were $90 \%$ and $84 \%$ for gay/lesbian/bisexual respondents-suggest that we are far from full and easy integration of such issues into the curriculum.

Further, how are we to judge the claim by a majority of chairs that a student wishing to focus a thesis on gay-related issues could find a supervisor within the department, when so few political scientists send out any signals about being willing or able to engage in that kind of supervision? When so many departments are so clearly silent on the subject of sexual diversity, why would a student even consider such work?

\section{Conclusion}

There are mixed messages in the data provided by the 1993 APSA surveys, some of them difficult to interpret. Clearly, there has been some improvement; but just as clearly, there are areas of concern. Many of our findings are similar to those drawn from surveys of historians and sociologists a year earlier. These certainly do not suggest that the status of gay and lesbian political scientists is any more secure than that of historians or sociologists, nor that the climate in the political science profession is any more welcoming.

We have pointed to indicators of positive change, although we have also suggested that these do not cast quite as warm a glow as many members of the profession might imagine. We take some encouragement from the number of gays, lesbians, and bisexuals who report that as students they were helped or guided by mentors who knew of their sexual orientation and were undeterred by that knowledge. Increasing numbers of young scholars are presenting themselves as candidates for jobs without concealing their sexual orientation. And although many survey responses made clear that visibility has risks, those political scientists who were out tended to report that the benefits outweighed the costs. Finally, increased numbers of political scientists (including heterosexuals) are prepared to treat gay-related issues as subjects of serious inquiry.

Nonetheless, the status of sexual minorities, and of scholarly inquiry into gay and lesbian politics, remains marginal. That marginality is evident in the day-to-day experiences and perceptions of a substantial number of lesbians, gay men, and bisexuals, but it is not always evident to heterosexuals in the profession, including department chairs. Survey responses show an important gap between their perceptions and those of lesbians and gays themselves. "Climate" issues are difficult to gauge, especially when questions of perceived discrimination are at stake, but the contrast in perceptions is sufficiently stark to suggest that many heterosexuals, and some gays and lesbians themselves, do not recognize the subtle ways in which academic culture in general, and the culture of political science in particular, discriminates.

These issues assume particularly stark form in the case of lesbians and gays of color. The work of other committees and constituencies of the Association has aimed at redressing discrimination on lines of race, ethnicity, and gender. Those who are members of more than one group that is marginalized in the profession often face especially imposing obstacles to full inclusion. The small number of people of color who responded to this survey may reflect their particular experience of exclusion and enforced invisibility. This exclusion operates both at the level of representation in the profession and of research agendas.

How, then, are we to judge overall assessments by chairs that the institutional climate for gays and lesbians is moderately positive (their average response on a 10 point scale being 6.2)? The fact that they see the climate as improved from an average of 5.0 that they would have assigned five years ago provides some encouragement. It is hard to avoid being disheartened when they anticipate only modest improvement in the climate over the next five years. Even if we take chairs' responses at face value, we find much that is troubling. If we juxtapose them to the responses of gay/lesbian/bisexual political scientists, we have reason to believe that academics in positions of responsibility can all too easily overstate the inclusiveness of the climate in the departments over which they preside.

Around an issue that is still relatively new in the political arena, we all have a great deal to learn. What we are starting to learn suggests that we have only begun to cultivate an institutional environment that goes beyond mere tolerance of sexual differences toward full inclusion in the discipline.

\section{Notes}

1. This report was prepared for the Committee by Martha Ackelsberg, Smith College, and David Rayside, the University of Toronto. Kenneth Sherrill, of Hunter College, and Howard Gold, of Smith College, offered invaluable assistance with the data analysis. The report was developed, reviewed, and edited by all of the Committee on the Status of Lesbians and Gays in the Profession, including Mark Blasius, City University of New York-LaGuardia, chair; Cathy J. Cohen, Yale University; Shane Phelan, University of New Mexico; Sarah Slavin, State University of New York at Buffalo; Christine Di Stefano, University of Washington; and members of the Gay, Lesbian and Bisexual Caucus for Political Science, especially Kevin Williams, Washington University. Greg Lewis, American University; Murray Edelman, Voter Research and Surveys, New York; and Robert Bailey, Columbia University, contributed 
very helpful time and ideas. We are grateful to Michael Brintnall and the staff of the American Political Science Association for collection and initial coding of the survey data.

2. For purposes of this report, we use the term "sexual minorities" interchangeably with the phrase "gays, lesbians, and bisexuals." In general, the terminology with respect to sexual identities is in flux, and there is considerable debate about what terms are most appropriate. In some contexts, "sexual minorities" is used more broadly, to include, as well, transgendered persons and others of nondominant sexuality. Sometimes the term "queer" is used as the umbrella term. However, because the surveys on which we report asked only about gays, lesbians, and bisexuals, our comments refer only to members of those groups.

3. By comparison, the APSA established committees on the status of blacks and of women in 1968 (the first appointments to which were made in 1969), and on Chicanos (later Latinos) in 1969 (with first appointments made in 1970).

4. Largely the former, since the overwhelming majority of responses ( 359 questionnaires, $78 \%$ of the total) came from questionnaires distributed at the annual meetings - a good response rate for questionnaires distributed at these meetings. As a consequence, the sample is younger, and probably more professionally active, than the profession as a whole. In addition, it most likely consists of those with the strongest feelings on the topic, whether positive or negative.

5. See Verta Taylor and Nicole Raeburn, "Collective Identity in the Gay and Lesbian Movement: Coming Out as High-Risk Activism," manuscript, Department of Sociology, Ohio State University, April 30, 1993, p. 3.

6. The Departmental Services survey of department chairs, distributed at the same time as the Committee's survey, had a response rate of $56 \%$ among this same group. Of the 512 chairs of departments that did not offer any degree in political science, only 24 responded to the Committee's survey, while 157 responded to the Departmental Services questionnaire.

7. Of the membership sample as a whole, approximately $44 \%$ were tenured, $28 \%$ were untenured, $21 \%$ were graduate students, $3 \%$ were non-tenure track faculty, and $5 \%$ were part-time faculty. Approximately $64 \%$ of the sample was male and $36 \%$ female. Sixty-two percent were work- ing in Ph.D.-granting institutions, $15 \%$ in master's granting, $22 \%$ in four-year colleges, and $.5 \%$ in two-year colleges. As for the chairs' sample, $17 \%$ were from Ph.D.-granting institutions, approximately the same percentage from MA-granting institutions, $59 \%$ from four-year colleges, and $2 \%$ from twoyear institutions. Forty-six percent of responses from chairs were from public institutions, $12 \%$ from religious, and $42 \%$ from private.

8. "Committee on Women Historians' Report on the Lesbian and Gay Historians Survey," Perspectives (April 1993): 13-15; and Taylor and Raeburn, "Collective Identity."

9. Before it created this Committee, the APSA Council appointed a task force to develop a charter for it. The Committee on the Status of Lesbians and Gays in the Profession is the only APSA-status committee for which a charter was required before it could be established.

10. Incorporation of attention to issues of sexuality, for example, challenges conventional understandings of the distinction between public and private, and contributes to a broader conceptualization of our definition of "the political."

11. Two people resigned from the Association after the survey was distributed, attributing their resignations to, among other things, the inappropriateness of this research. See Oskar Gruenwald, "Forum: Opposition to APSA's Domestic Partners Policy," PS March 1994. The Committee's reply was printed in the same "Forum."

12. Taylor and Raeburn, "Collective Identity in the Gay and Lesbian Movement," p. 3.

13. See also Dorothee Benz, "Sex and Community Before and After Stonewall," paper presented at the 1994 Annual Meeting, American Political Science Association, New York, N.Y.

14. "Committee on Women Historians' Report," p. 13.

15. Taylor and Raeburn, Table 3. They note that $48 \%$ of men, as opposed to $36 \%$ of women, reported experiencing discrimination on the basis of gender orientation. But they suggest that this could be a consequence either of the fact that men are much more likely than women are to be out to their colleagues, or of the difficulty women may have of distinguishing between discrimination based on gender and that based on sexual orientation. A similar pattern (greater tendency for men to be fully out on campus, and also for men to report having experienced discrimination on the basis of sexual orientation with greater frequency than do women) exists among political scientists. See below.

16. Among historians responding to the survey, $64 \%$ were out to chairs; among sociologists, $54 \%$ were out to most colleagues.

17. The Gay, Lesbian, Bisexual Political Science Caucus has 161 people on its mailing list, some of whom are heterosexual.

18. Degrees of being "out" are difficult to quantify. The figures that follow were derived from a question that left room for a number of possible interpretations. We included in the category of "out" those lesbians, gays, and bisexuals who said they were "out to everyone," as well as those who said they were out to at least three of the following five: chair, most colleagues, most students, most staff, senior administration. Included in the "not out" category were those who identified themselves as "out to no one," or "out only to other gays and lesbians"' on campus.

19. Among sociologists, $60 \%$ of those in non-tenure track positions are out to most colleagues, as opposed to $38 \%$ of those who are untenured but in tenure-track positions, and $48 \%$ of those with tenure. Perhaps those who are in non-tenure track positions feel they have nothing to lose by being out, since nothing more is at stake for them at the institution; perhaps we are seeing an age- or cohort-related difference: those in non-tenure track positions are mostly younger faculty members who, having "grown up" in a social/political context in which "coming out" is more common, are less fearful than their elders, and will carry that tendency to be "out" into the tenuretrack ranks once they are offered such positions.

20. Among those with tenure, $58 \%$ reported that their job would definitely or probably not be at risk, and only $6 \%$ said it definitely would be at risk.

21. Of the historians and sociologists surveyed in $1992,50 \%$ and $22 \%$ respectively claimed a degree of exclusion from such networks.

22. For a discussion of the inclusion of gay/lesbian/bisexual issues into the political science curriculum, see Ron Hunt, "Gay and Lesbian Politics," PS, Vol. XXV, No. 2 (June 1992): 220-24. The Committee on the Status of Lesbians and Gays in the Profession is also undertaking a curriculum infusion project to address these concerns. 


\section{Appendix}

Selected Data from Survey of Department Chairs* on the Status of Lesbians and Gays in the Profession, 1993

1. How many faculty members in your department are known to you to be lesbian or gay? Total of 49 full-time faculty members

$0.2 \%$ of total number of full-time faculty in those institutions

2. Do you know of any openly gay, lesbian, or bisexual students in your department?

Undergraduate students: yes $38 \%$ no $41 \% \mathrm{dk} / \mathrm{na} 22 \%$

Graduate students: yes $10 \%$ no $23 \%$ dk/na $67 \%$

3. How might the following activities by gay or lesbian colleagues be perceived by yourself in your role as chair, by your department, and in your institutions as a whole? (Percentages refer to "accepted," "tolerated with some discomfort," and "considered inappropriate.")

A. Overall responses

presenting paper on lesbian/gay topic at APSA

including gay/lesbian topics in a course

commenting on gay/lesbian issues in popular media

advocacy work on gay/lesbian issues in the community

identifying oneself as gay or lesbian in the classroom

B. Regional differences in perceived institutional response

presenting paper on gay/lesbian topic at APSA

including gay/lesbian topics in a course

commenting on gay/lesbian issues in popular media

advocacy work in the community

identifying oneself as gay/lesbian in the classroom

C. Differences in perceived institutional response by type of institution

presenting paper on gay/lesbian topic at APSA

including gay/lesbian topics in a course

commenting on gay/lesbian issues in popular media

advocacy work in the community

identifying oneself as gay/lesbian in the classroom
$\%$ accepted/tolerated/inappropriate

\begin{tabular}{lll}
\hline Yourself & Dept & $\frac{\text { Institution }}{73 / 12 / 4}$ \\
$86 / 3 / 3$ & $81 / 4 / 3$ & $60 / 22 / 6$ \\
$82 / 7 / 3$ & $73 / 11 / 3$ & $48 / 32 / 7$ \\
$82 / 8 / 3$ & $73 / 11 / 3$ & $39 / 35 / 13$ \\
$76 / 9 / 8$ & $67 / 12 / 8$ & $31 / 31 / 23$
\end{tabular}

Percent "accept"

\begin{tabular}{|c|c|c|c|}
\hline North & West & Midwest & South \\
\hline 85 & 90 & 80 & 78 \\
\hline 75 & 74 & 69 & 59 \\
\hline 57 & 67 & 57 & 47 \\
\hline $\begin{array}{l}61 \\
49\end{array}$ & $\begin{array}{l}56 \\
49\end{array}$ & $\begin{array}{l}41 \\
30\end{array}$ & $\begin{array}{l}32 \\
24\end{array}$ \\
\hline
\end{tabular}

Percent "accept"/ "inappropriate"

\begin{tabular}{llc} 
Public & Private & Religious \\
\cline { 2 - 2 } $89 / 3$ & $81 / 1$ & $64 / 18$ \\
$70 / 5$ & $72 / 7$ & $47 / 13$ \\
$65 / 9$ & $52 / 6$ & $33 / 15$ \\
$50 / 9$ & $47 / 16$ & $21 / 33$ \\
$44 / 17$ & $37 / 28$ & $12 / 58$
\end{tabular}

4. Does your college or university have a nondiscrimination policy that includes sexual orientation? yes $65 \%$ no $21 \%$ dk/na $14 \%$

5. Does your campus offer benefits to spouses of employees such as health care or access to campus facilities? no $8 \%$

If yes, does it offer benefits to nonmarried domestic partners? no $42 \%$ dk/na $47 \%$

* Percentage totals may differ from $100 \%$ because of rounding. 
6. Are there faculty development funds in your institution targeted for "diversity"? yes $47 \%$ no $37 \% \mathrm{dk} / \mathrm{na} 16 \%$ If yes, are gay/lesbian issues included? yes $13 \%$ no $15 \% \mathrm{dk} / \mathrm{na} 73 \%$

7. Is there a gay/lesbian student organization on your campus? yes $60 \%$ no $32 \%$ dk/na $9 \%$ Does it receive any institutional support? yes $35 \%$ no $9 \% \quad \mathrm{dk} / \mathrm{na} 56 \%$

8. How many full-time faculty members in your department have published on gay/lesbian topics? none $65 \%$ one or more $9 \% \mathrm{dk} / \mathrm{na} 26 \%$

9. Have there been any applicants for positions in your department who were openly lesbian or gay? yes $11 \%$ no $40 \%$ dk/na $49 \%$

10. To your knowledge, have there been any applicants for positions who have indicated research or teaching interests in the field of lesbian or gay politics? yes $16 \%$ no $60 \% \mathrm{dk} / \mathrm{na} 24 \%$ If yes, was that considered an asset, a liability, or neither? asset $3 \%$ liability $1 \%$ neither $15 \% \mathrm{dk} / \mathrm{na} 82 \%$

11. Has your department ever sponsored a lecture on gay/lesbian politics? frequently 0 occasionally $9 \%$ rarely $13 \%$ never $74 \%$ na $5 \%$

12. How many courses does your department offer including gay/lesbian topics? graduate, as a primary theme: none $34 \%$ one or more $1 \% \mathrm{dk} / \mathrm{na} 65 \%$ graduate, as topic or unit: none $23 \%$ one or more $6 \% \mathrm{dk} / \mathrm{na} 71 \%$ undergraduate, as primary theme: none $66 \%$ one or more $3 \% \mathrm{dk} / \mathrm{na} 32 \%$ undergraduate, as topic or unit: none $31 \%$ one or more $35 \% \mathrm{dk} / \mathrm{na} 34 \%$

13. Have there been any Ph.D, MA or undergraduate theses on lesbian/gay topics? yes $10 \%$ no $64 \%$ dk/na $26 \%$

If a student wished to write such a thesis, how likely would s/he be to find an advisor from within the department? very likely $54 \%$ somewhat likely $17 \%$ unlikely $4 \% \quad \mathrm{dk} / \mathrm{na} 25 \%$

\section{Congressional Fellowship Program Announces 1995-96 Competition Winners}

The American Political Science Association has announced the winners in the national competition for the 1995-96 Congressional Fellowship Program. Following a onemonth orientation seminar, Fellows work full time for nine months as professional staff assistants to members of Congress or congressional committees.

The new Political Science and Journalism Congressional Fellows are:

William J. Drake, Assistant Professor, Department of Communication, University of California, San Diego

Robert A. Franklin, General Manager, WESM-FM, University of Maryland, Eastern Shore

Dimitra Kessenides, Freelance Writer, Athens, Greece

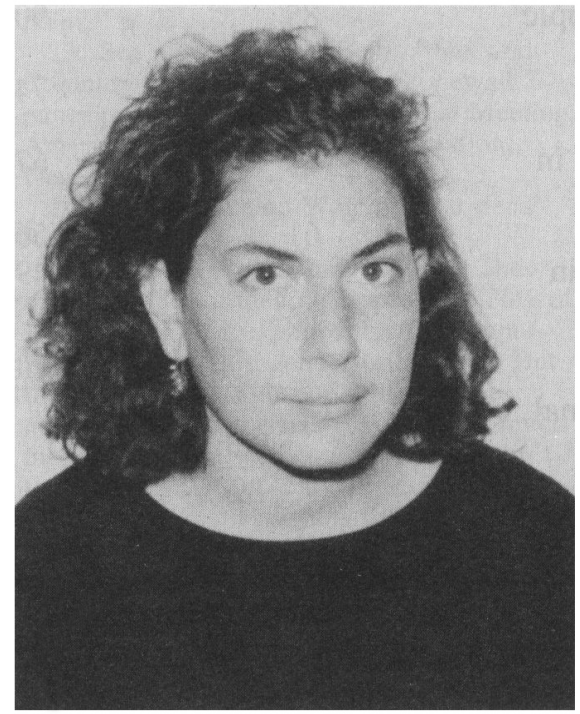

Dimitra Kessenides

Jessica Korn, Assistant Professor, Department of Political Science, University of Massachusetts at Amherst

Laureen Lazarovici, Writer, California Journal, Sacramento

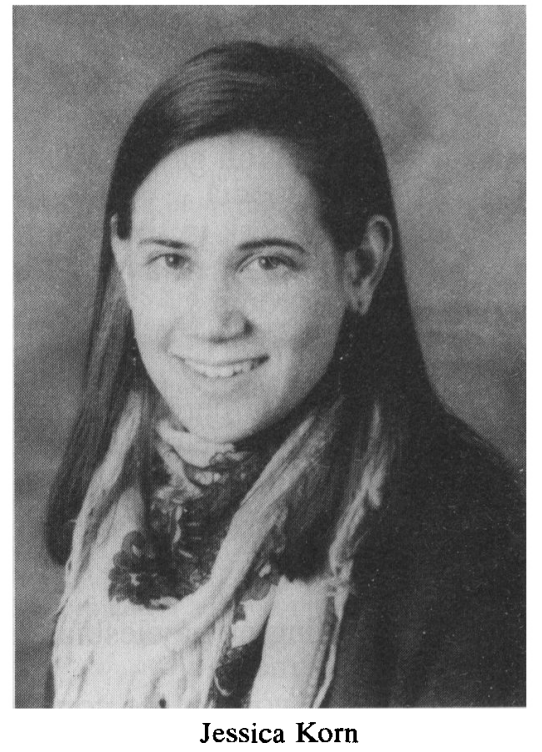

Diana M. Owen, Assistant Professor, Department of Government, Georgetown University

Nicol Rae, Associate Professor, Department of Political Science, Florida International University 